\title{
Prevalence and Morphological Types of Anaemia among Children Under-Five Years in the Volta Regional Hospital of Ghana
}

\author{
Joseph Adu-Amankwaah1, Emmanuel Alote Allotey', David Annor Kwasie'2, Innocent Afeke1, \\ Patrick Kwasi Owiafe ${ }^{1}$, Paul Chukwuemeka Adiukwu ${ }^{3}$, Orish Verner Ndudiri4* \\ ${ }^{1}$ Department of Medical Laboratory Science, School of Allied Health Science, University of Health and Allied Sciences, Ho, Ghana \\ ${ }^{2}$ Laboratory Department, Volta Regional Hospital, Ho, Ghana \\ ${ }^{3}$ Department of Pharmaceutical Chemistry, School of Pharmacy, Ho, Ghana \\ ${ }^{4}$ Department of Microbiology and Immunology, School of Medicine, University of Health and Allied Sciences, Ho, Ghana \\ Email: *orishv@yahoo.com
}

How to cite this paper: Adu-Amankwaah, J., Allotey, E.A., Kwasie, D.A., Afeke, I., Owiafe, P.K., Adiukwu, P.C. and Ndudiri, O.V. (2018) Prevalence and Morphological Types of Anaemia among Children Under-Five Years in the Volta Regional Hospital of Ghana. Open Access Library Journal, 5: e4351.

https://doi.org/10.4236/oalib.1104351

Received: January 18, 2018

Accepted: February 23, 2018

Published: February 26, 2018

Copyright $\odot 2018$ by authors and Open Access Library Inc.

This work is licensed under the Creative Commons Attribution International License (CC BY 4.0).

http://creativecommons.org/licenses/by/4.0/

\section{(c) (i) Open Access}

\begin{abstract}
Background: This study aimed at determining the prevalence and morphological types of anaemia, among children under-five years, who had full blood count (FBC) investigation done at the laboratory of the Volta regional hospital. Methodology: This was a retrospective study of archival FBC test results data for children below 5 years in the laboratory, between $1^{\text {st }}$ July to $31^{\text {st }}$ December 2015. The FBC results comprised of the hemoglobin $(\mathrm{Hb})$ concentration and the red blood cell indices. Obtained data were analyzed using SPSS version 20.0. Results: A total 451 children were sampled. Anaemia prevalence in this study was $55.0 \%(248 / 451)$ and most of the children suffered from moderate anaemia (42\%) (104/248) with mild and severe anaemia being $34 \%$ $(84 / 248)$ and $24 \%(60 / 248)$ respectively. Children with microcytic hypochromic anaemia were $52 \%,(130 / 248)$, while those with normocytic normochromic were $25 \%$ (63/248). Conclusion: Anaemia was found in more than half of the children under-five years and microcytic hypochromic anaemia was the commonest morphological type of anaemia. There is need for a multi-disciplinary approach to elucidate the etiology of anaemia in children under-five years.
\end{abstract}

\section{Subject Areas}

Hematology

\section{Keywords}

Anaemia, Microcytic Hypochromic Anaemia, Full Blood Count, Red Cell Indices, Nutrition 


\section{Introduction}

Anaemia is a major public health problem in both developing and industrialised countries with major consequences for human health, as well as social and economic development [1]. It is estimated that about 3.5 billion people in the developing countries are anaemic [2]. In 2009, The World Health Organization (WHO) estimate of anaemia prevalence in Africa was $64.6 \%$, which is about four folds the prevalence in Europe (16.4\%) [2]. The global estimate of childhood anaemia indicates that 293.1 million of children under-five years are anaemic and $28.5 \%$ of these children reside in Africa. Anaemia is considered to be a major public health problem in Africa, because it is the cause of death for most children admitted to hospitals in Africa [2]. Even where blood transfusion is available, there is a significant case fatality rate of $6 \%-18 \%$ [3].

Anaemia can occur at all stages of human life, but is more common in pregnant women and young children. Anaemia is basically caused by inadequate intake of nutrients, haemoglobinopathies, infections or a combination of some these [2]. Inadequate intake of iron rich and other essential micro nutrients will predispose children to iron and other nutrients deficiency anaemia [4]. Infections also play a great role in causing anaemia basically by interfering with nutrients intake, absorption and assimilation [2]. Intestinal helminths like Hookworm, Ascaris lumbricoides, Tricuris tricuria and Schistosoma haematobium are responsible for some anaemia seen in children especially in areas of poor environmental sanitation [5]. Malaria can cause anaemia basically from excessive destruction of red blood cells [6]. Children under-five years are highly vulnerable to malaria because of rudimentary clinical and parasitic immunity [7]. Anaemia in children is of particular significance and interest since it leads to the impairment of their mental, physical and social development, causing negative behavioural and cognitive effects resulting in poor school performance and work capacity in later years [8].

According to Ghana statistical service, the national and regional estimates of the prevalence of anaemia provided in the 2008 Ghana Demographic and Health Survey Report indicates that $78.4 \%$ of the overall population is anaemic, $84.1 \%$ are resident in rural areas while $67.9 \%$ are in urban areas [9]. A comprehensive study of childhood anaemia in the Ghanaian population using data generated from the Ghana Demographic and Health Survey (GDHS) revealed that the overall prevalence of anaemia among children under-five was $78.4 \%$, where $7.8 \%$ of the children had severe, $48 \%$ moderate and $22.6 \%$ had mild anaemia. This indicates that over $55 \%$ of the children were at least moderately anaemic. Of all the ten regions in the country, the upper east and upper west region recorded the highest prevalence with $88.9 \%$ and $88.1 \%$ respectively [10].

Though national and regional estimates of the prevalence of anaemia are available in Ghana, what is widely unknown is the prevalence within specific socio-demographic subgroups. Due to this lack of information, directing the limited resources to the appropriate target areas is mostly a challenge and a con- 
tributing factor to missing the real target population. This study looked at the prevalence of anaemia, its severities and morphological types among children under-five years at the Volta Regional Hospital of Ghana.

\section{Methodology}

\subsection{Study Area and Population}

The Volta regional hospital is a tertiary heath institution located in Ho municipality, the administrative capital Volta region of Ghana. The Volta region is one of the ten regions in Ghana. It is located between latitudes $50^{\circ} 45^{\prime \prime} \mathrm{N}$ and $80^{\circ} 45^{\prime \prime} \mathrm{N}$ in the south-eastern part of the country bounded by Togo on the east and Lake Volta on the west. The study was carried out in the haematology unit of the laboratory of Volta regional hospital (VRH) in Ho municipal, which serves as the regional hospital in the region. Haematological laboratory records of children under-five years were reviewed in this study. The haematology unity of the laboratory, records a yearly average of 15,000 patients and about 1000 children under the age of 5 years, for full blood count investigations.

\subsection{Study Design}

The research was a retrospective study which involved reviewing of records in the laboratory department of the Volta regional hospital. The sampling structure for this study was the full blood count register in the haematology unit which contains results for both in and outpatient of the hospital. Six months archival data from $1^{\text {st }}$ July to $31^{\text {st }}$ December, 2015 were retrieved and reviewed to determine the prevalence and the morphological types of anaemia in children under-five years. Data on haemoglobin and red blood cell indices were collected. The study excluded children with HIV and other haemoglobinopathies.

\subsection{Ethical Consideration}

Permission for the commencement of the research was granted by the authorities of the Volta regional hospital.

\subsection{Data Collection}

Data was obtained from the records of the haematology unit of the Volta regional hospital's laboratory which comprised of full blood count (FBC) results of children less than five years. The full blood count results comprised of the haemoglobin $(\mathrm{Hb})$ concentration and the various red blood cell indices such as mean cell volume (MCV), mean cell haemoglobin (MCH), mean cell and haemoglobin concentration (MCHC). Anaemia was defined based on WHO criteria of mild $(<11 \mathrm{~g} / \mathrm{dl})$, moderate $(<10 \mathrm{~g} / \mathrm{dl})$ and severe $(<7 \mathrm{~g} / \mathrm{dl})$ [11]. The anaemia was further classified based on the various red blood cell indices.

\subsection{Morphological Types of Anaemia Based on Red Cell Indices}

The red blood cell (RBC) indices describe the average size and haemoglobin 
(Hb) content of red blood cells. They are also called red cell absolute values or erythrocyte indices. MCV indicates the average volume of red blood cells expressed in femtoliters (fl). An increase, normal, or decreased MCV indicates that the average $\mathrm{RBC}$ is macrocytic, normocytic, or microcytic respectively. $\mathrm{MCH}$ measures the average weight of haemoglobin in a red blood cell expressed in picograms (pg). A normal or decreased $\mathrm{MCH}$ tends to show that $\mathrm{RBC}$ is normochromic or hypochromic respectively. The MCHC measures the average concentration of haemoglobin in a red blood cell. The MCHC categorizes red blood cells according to their concentration of hemoglobin. Cells with a normal concentration of hemoglobin are called normochromic; cells with a lower than normal concentration are called hypochromic. Because there is a physical limit to the amount of hemoglobin that can fit in a cell, there is no hyperchromic category. Generally, the MCV and MCH values are used in morphological classification of anaemia [12].

However MCH values usually remain normal or fall as the MCV is increased, normal or decreased in cases of anaemia (thus low Hb) [12]. Normal MCV with normal $\mathrm{MCH}$ but low $\mathrm{Hb}$ indicates normocytic normochromic anaemia; normal MCV with decreased MCH tends to show normocytic hypochromic anaemia; decreased MCV with normal MCH indicates microcytic normochromic anaemia; and decreased MCV with decreased $\mathrm{MCH}$ indicates microcytic hypochromic anaemia. The normal reference ranges for the various RBC indices are shown in Table 1 below.

\subsection{Haemoglobin and Other Red Blood Cell Indices Estimation}

Haemoglobin and other red blood cell indices estimation was performed using, automated haematology analyzer (Sysmex, Kakogawa, Japan).

\subsection{Statistical Analysis}

The statistical analysis of the data was done using SPSS (Statistical Package for Social Sciences) version 20.0. The analysis was used to determine the prevalence of anaemia in children less than 5 years in the haematology unit of the Volta regional hospital's laboratory and also classify the anaemia based on the red blood cell indices. Data was represented as frequency tables and graphs. Children under-five years were further categorised into different age groups and Pearson chi square test was used to determine their associations with the different morphological types of anaemia and Anova was used to determine the mean haemoglobin concentration among the different age groups. Analyses were done with $95 \%$

Table 1. Dacie and Lewis practical haematology, $10^{\text {th }} \mathrm{Ed}$.

\begin{tabular}{ccc}
\hline RED CELL INDICES & 1 year & 2 - 5 years \\
\hline Mean cell volume (MCV) pg & $34 \pm 4$ & $37 \pm 3$ \\
Mean cell haemoglobin (MCH) fl & $78 \pm 6$ & $81 \pm 6$ \\
Mean cell haemoglobin concentration $(\mathrm{MCHC}) \mathrm{g} / \mathrm{dl}$ & $34 \pm 2$ & $34 \pm 3$ \\
\hline
\end{tabular}


confidence interval (CI) and $p \leq 0.05$ was considered statistically significant.

\section{Result}

\subsection{General Profile}

There were a total of 7284 patients that visited Volta Regional Hospital's Laboratory for Full Blood Count (FBC) investigation during the study period of $1^{\text {st }}$ July, 2015 to $31^{\text {st }}$ December, 2015. Of these, 451 were children under-five years of age. A total of 248 (55\%) children under the age of 5 years were anaemic.

Table 2 describes some characteristics of the 248 anaemic children in this study. There were more females $(50.40 \%, 125 / 248)$ than males $(49.60,123 / 248)$ anaemic in this study. Children between the ages of 1 and 2 years $(29.40 \%$, $74 / 248$ ) constituted the highest proportion among the 248 anaemic children. It also shows the prevalence of the severity of the anaemia, with majority of the children moderately anaemic $(42 \%, 104 / 248)$, followed by mild anaemia $(34 \%$, $84 / 248)$ and the lowest number of children severely anaemic (24\%, 60/248). Microcytic hypochromic anaemia $(52.42 \%, 130 / 248)$ was the most prevalent morphological types of anaemia and normocytic hypochromic anaemia $(5.24 \%$, 13/248) the least.

\subsection{Morphological Types of Anaemia}

Table 3 stratified the children based on age group. The mean haemoglobin

Table 2. Baseline characteristics of 248 children under-five years of age with anaemia.

\begin{tabular}{ccc}
\hline CHARACTERISTICS & N & $(\%)$ \\
\hline SEX & 123 & 49.60 \\
Male & 125 & 50.40 \\
Female & & \\
AGE & 52 & 20.97 \\
$<1$ yr & 74 & 29.84 \\
$1 \leq$ age $<2$ yrs & 47 & 18.95 \\
$2 \leq$ age $<3$ yrs & 35 & 14.11 \\
$3 \leq$ age $<4$ yrs & 40 & 16.13 \\
$4 \leq$ age $\leq 5$ yrs & & \\
SEVERITY & 60 & 24.20 \\
Severe & 104 & 41.90 \\
Moderate & 84 & 33.90 \\
Mild & & \\
Microcytic hypochromic & 63 & 25.40 \\
MoRPHOLOGICAL TYPES OF ANAEMIA & 13 & 5.24 \\
Normocytic normochromic & 42 & 16.94 \\
Normocytic hypochromic & 52.42 \\
\hline Microcytic normochromic & &
\end{tabular}


Table 3. Characteristics of children stratified by age group.

\begin{tabular}{|c|c|c|c|c|c|c|c|}
\hline PARAMETER & & $\begin{array}{c}<1 \mathrm{yr} \\
\mathrm{N}=155(\%)\end{array}$ & $\begin{array}{c}1 \leq \text { age }<2 \text { yrs } \\
\mathrm{N}=103(\%)\end{array}$ & $\begin{array}{c}2 \leq \text { age }<3 \text { yrs } \\
N=79(\%)\end{array}$ & $\begin{array}{c}3 \leq \text { age }<4 \text { yrs } \\
\mathrm{N}=52(\%)\end{array}$ & $\begin{array}{c}4 \leq \text { age } \leq 5 \mathrm{yrs} \\
\mathrm{N}=62(\%)\end{array}$ & P-VALUE \\
\hline $\begin{array}{l}\text { PREVALENCE OF } \\
\text { ANAEMIA }\end{array}$ & & $52(33.45 \%)$ & $74(71.80 \%)$ & $47(59.50 \%)$ & $35(67.30 \%)$ & $40(64.50)$ & $<0.001$ \\
\hline \multirow[t]{2}{*}{ MEAN HB \pm SD } & & $12.76 \pm 3.59$ & $9.7 \pm 2.49$ & $9.68 \pm 2.51$ & $9.58 \pm 2.93$ & $9.33 \pm 255$ & $<0.001$ \\
\hline & $\begin{array}{c}\text { Normocytic } \\
\text { normochromic }\end{array}$ & $11(21.15 \%)$ & $14(18.92 \%)$ & $15(31.90 \%)$ & $11(31.40 \%)$ & $12(30.00 \%)$ & \\
\hline \multirow[t]{3}{*}{$\begin{array}{l}\text { MORPHOLOGIGAL } \\
\text { TYPES OF ANAEMIA }\end{array}$} & $\begin{array}{l}\text { Normocytic } \\
\text { hypochromic }\end{array}$ & $5(9.62 \%)$ & $5(6.76 \%)$ & $1(2.10 \%)$ & $0(0.00 \%)$ & $2(5.00 \%)$ & \\
\hline & $\begin{array}{c}\text { Microcytic } \\
\text { normochromic }\end{array}$ & $11(21.15 \%)$ & $4(5.40 \%)$ & $7(14.90 \%)$ & $8(22.90 \%)$ & $12(30.00 \%)$ & 0.008 \\
\hline & $\begin{array}{l}\text { Microcytic } \\
\text { hypochromic }\end{array}$ & $25(48.10 \%)$ & $51(68.92 \%)$ & $24(51.10 \%)$ & $16(45.70 \%)$ & $14(35.00 \%)$ & \\
\hline
\end{tabular}

$\mathrm{P}$ values derived from Pearson chi-square test for categorical variables and ANOVA for the mean of continuous variables. $¥ \mathrm{~N}=248$. Chi-square value $=$ $45.046^{\mathrm{a}}$.

decreases significantly $(p<0.001)$ with increase in age. The prevalence of anaemia was lowest among children below 1 year $(33.45 \%, 52 / 155)$ and highest among between the ages of 1 to 2 years $(71.80 \%, 74 / 103)(p<0.001)$. Additionally, there was a significant $(p=0.008)$ difference between the morphological types of anaemia among the various age groups with children between ages of 1 2 years having the highest prevalence of microcytic hypochromic anaemia (68.92\%, 51/74).

Figure 1 and Figure 2 are blood pictures of normocytic normochromic and microcytic hypochromic anaemia respectively.

\section{Discussion}

The findings of this study revealed that more than half of the children under the age of five who had FBC investigations in the haematology unit of the Volta regional hospital's laboratory presented with anaemia (55.0\%). Anaemia among children under-five years of age is a proven public health problem as several community and hospital based studies in developing countries have reported significant burden among this vulnerable age group [12] [13] [14] [15]. The prevalence in this study was much lower compared to the Ghana Demographic and health survey of 2008 . The overall prevalence of anaemia, gotten from the survey among children under-five years of age was $78 \%$ and $79.5 \%$, nationwide and Volta region respectively [10]. The lower prevalence of anaemia in this study compared with the prevalence recorded by the estimates from the Ghana demographic and health survey could be as a result of the geographical location of the study participants. The Volta regional capital (Ho) where this study was carried out is an urban area with minimal representation of rural children visiting the hospital as compared to the respondents used in the study done by demographic survey, where the survey data captured the entire Volta region of Ghana which is predominantly 


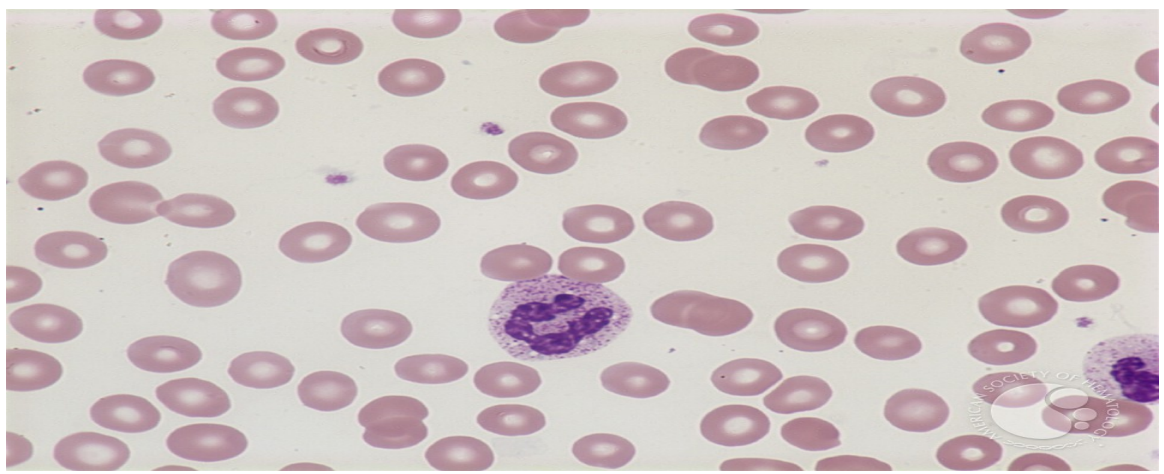

Figure 1. Normocytic normochromic anaemia.

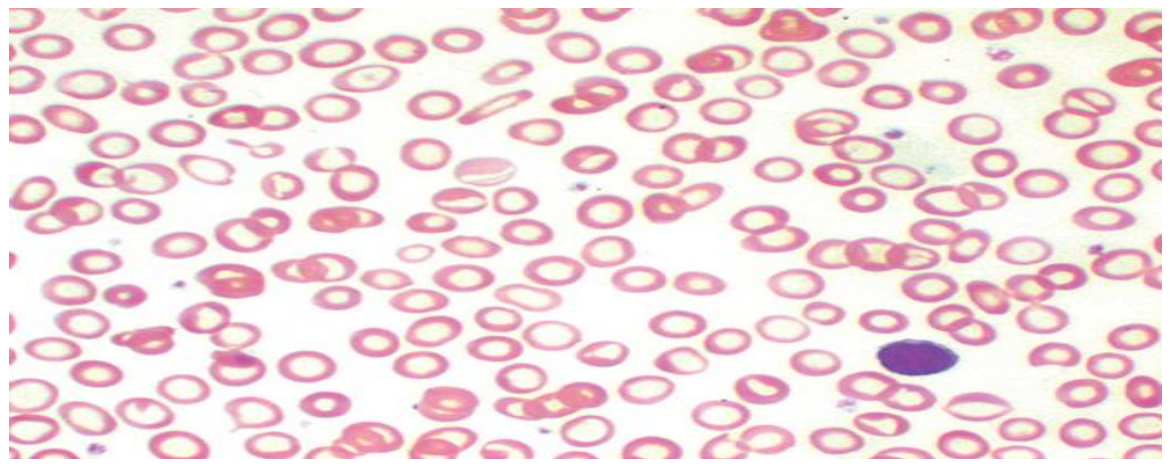

Figure 2. Microcytic hypochromic anaemia.

rural. Poverty and illiteracy are mostly widespread in rural communities in Ghana, two factors that impact negatively on the nutrition of children and ultimately their haemoglobin levels [16]. Additionally, the lower prevalence rate may be due to the efforts made by Government agencies and nongovernmental organizations to help improve the nutrition of children over the years. The interventions implemented include nationwide promotion of exclusive breastfeeding for the first 6 months of life, appropriate complementary feeding at 6 months with continued breastfeeding until 2 years and vitamin A and iron supplementation for children aged 6 months to 5 years [10]. Another very important factor that might explain the lower prevalence in this study compared to the demographic survey, is the fact that this is a hospital based study with smaller sample size. However, comparing this study to a hospital based study done in western region of Ghana the prevalence of anaemia was higher in the Volta regional hospital [17].

There was low prevalence of anaemia among children under one year seen in this study, compared to the other age groups. This finding is in contrast with some studies that have reported higher prevalence of anaemia among infants, especially those who still breast fed [18] [19] [20]. Prolong breast feeding increases the risk of anaemia since the breast milk is not sufficient in supplying iron to the rapidly growing infant [19] [20]. Our study did not take into account the breast-feeding pattern of these children, but it is likely that these infants were on complementary feeding enough to boost their iron requirement. However, 
the high prevalence of anaemia in children between 1 and 2 years also seen in this study, might be due to susceptibility of these group to infections which usually affected their nutrition and feeding and thus decreased their ability to ingest and absorb iron [21].

Based on red cell indices, microcytic hypochromic anaemia was the highest morphological type of anaemia seen among the children under-five years of age in this study. Microcytic hypochromic anaemia among children under-five years has been reported in some other studies [22] [23]. It is commonly caused by iron deficiency, thalassemia syndromes, anaemia of chronic disease and sideroblastic anaemia [24]. In this study, it is likely that the cause of the microcytic anaemia is iron deficiency since children with haemoglobinopathies were excluded from this study. It might be linked to unbalanced food intake, poor iron stores and other nutritional deficiencies among these children [23].

Normocytic normochromic anaemia was the second most common type of anaemia (25\%) in this study. It is normally caused by haemolytic anaemia (e.g. malaria), hereditary spherocytosis and early or partially treated iron or vitamin deficiency [25].

\section{Limitation}

This is a retrospective study that looked only at the records available over a 6 months period. This might not be true reflection of the prevalence of anaemia among children that visited the hospital during that period, as some children who came to the hospital during the period might not have had a FBC done on them. More so, the clinical conditions and diagnosis of these children were not known, to throw more light on the different forms of anaemia seen in this study.

\section{Conclusion}

From this study, the prevalence of anaemia among children under-five years in the Volta regional hospital was 55.0\%. Majority of the children suffered from moderate anaemia (42\%) with mild and severe anaemia being $34 \%$ and $24 \%$ respectively. Microcytic hypochromic anaemia was the commonest morphological type of anaemia among the children. The findings of this study can be used as justification for further research into practices, belief systems and knowledge of anaemia by the caretakers and parents of children under-five years in the region. Health education on anaemia prevention should be intensified with emphasis on proper dietary practices by parents and caretakers for children especially during weaning and early childhood.

\section{Recommendation}

The findings of this study can be a justification to do further studies into practices, belief systems and knowledge of anaemia by the caretakers and parents of children under-five years in the region. This would help in proper policy formulation and implementation. 
Health education on anaemia prevention should be intensified with emphasis on proper dietary practices by parents and caretakers for children especially during weaning and early childhood.

\section{References}

[1] Nutrition, Sub-Committee on Coordination and Administrative Committee on Coordination (2000) 4th Report on the World Nutrition Situation. Nutrition throughout the Life Cycle. ACC/SCN/WHO, Geneva.

[2] McLean, E., Cogswell, M., Egli, I., Wojdyla, D. and De Benoist, B. (2009) Worldwide Prevalence of Anaemia, WHO Vitamin and Mineral Nutrition Information System, 1993-2005. Public Health Nutrition, 12, 444-454.

https://doi.org/10.1017/S1368980008002401

[3] Schellenberg, D., Schellenberg, J.R.M., Mushi, A., Savigny, D., Mgalula, L., Mbuya, C. and Cesar Gomes, V. (2003) The Silent Burden of Anaemia in Tanzanian Children: A Community-Based Study. Bulletin of the World Health Organization, 81, 581-590.

[4] Özdemir, N. (2015) Iron Deficiency Anaemia from Diagnosis to Treatment in Children. Turkish Archives of Pediatrics/ Türk Pediatri Arşivi, 50, 11-19. https://doi.org/10.5152/tpa.2015.2337

[5] Osazuwa, F., Ayo, O.M. and Imade, P. (2011) A Significant Association between Intestinal Helminth Infection and Anaemia Burden in Children in Rural Communities of Edo State, Nigeria. North American Journal of Medical Sciences, 3, 30-34. https://doi.org/10.4297/najms.2011.330

[6] Austin, N.I.R., Adikaibe, E.A.B., Ethelbert, O.O., Chioma, U.E. and Ekene, N.U. (2014) Prevalence and Severity of Malaria Parasitemia among Children Requiring Emergency Blood Transfusion in a Tertiary Hospital in Imo State, Nigeria. Annals of Medical and Health Sciences Research, 4, 619-623. https://doi.org/10.4103/2141-9248.139349

[7] Okiro, E.A., Al-Taiar, A., Reyburn, H., Idro, R., Berkley, J.A. and Snow, R.W. (2009) Age Patterns of Severe Paediatric Malaria and Their Relationship to Plasmodium Falciparum Transmission Intensity. Malaria Journal, 8, 4.

[8] Villalpando, S., Shamah-Levy, T., Ramírez-Silva, C.I., Mejía-Rodríguez, F. and Rivera, J.A. (2003) Prevalence of Anaemia in Children 1 to 12 Years of Age: Results from a Nationwide Probabilistic Survey in Mexico. Salud pública de México, 45, 490-498.

https://doi.org/10.1590/S0036-36342003001000005

[9] Ghana Statistical Service, Ghana Health Service and ICF Macro (2009) Ghana Demographic and Health Survey, 2008. Ghana Statistical Service, Ghana Health Service, and ICF Macro, Accra.

[10] Ewusie, J.E., Ahiadeke, C., Beyene, J. and Hamid, J.S. (2014) Prevalence of Anaemia among Under-Five Children in the Ghanaian Population: Estimates from the Ghana Demographic and Health Survey. BMC Public Health, 14, 626.

[11] World Health Organization (1989) Preventing and Controlling Iron Deficiency Anaemia through Primary Health Care.

http://wwwwhoint/nutrition/publications/micronutrients/anaemia_iron_deficiency 19241542497.pdf.

[12] Leite, M.S., Cardoso, A.M., Coimbra, C.E., Welch, J.R., Gugelmin, S.A., Lira, P.C.I., Horta, B.L., Santos, R.V. and Escobar, A.L. (2013) Prevalence of Anaemia and Associated Factors among Indigenous Children in Brazil: Results from the First $\mathrm{Na}$ - 
tional Survey of Indigenous People's Health and Nutrition. Nutrition Journal, 12, 69. https://doi.org/10.1186/1475-2891-12-69

[13] Foote, E.M., Sullivan, K.M., Ruth, L.J., Oremo, J., Sadumah, I., Williams, T.N. and Suchdev, P.S. (2013) Determinants of Anaemia among Preschool Children in Rural, Western Kenya. The American Journal of Tropical Medicine and Hygiene, 88, 757-764. https://doi.org/10.4269/ajtmh.12-0560

[14] Heckman, J., Samie, A., Bessong, P., Ntsieni, M., Hamandi, H., Kohler, M., Milam, B., Scriver, J. and Dillingham, R. (2010) Anaemia among Clinically Well Under-Fives Attending a Community Health Centre in Venda, Limpopo Province. SAMJ: South African Medical Journal, 100, 445. https://doi.org/10.7196/SAMJ.3579

[15] Magesa, A.S. and Magesa, P.M. (2014) Association between Anaemia and Infections (HIV, Malaria and Hookworm) among Children Admitted at Muhimbili National Hospital. East African Journal of Public Health, 9, 96-100.

[16] El Hioui, M., Farsi, M., Aboussaleh, Y., Ahami, T., Omar, A. and Achicha, A. (2010) Prevalence of Malnutrition and Anaemia among Preschool Children in Kenitra, Morocco. Nutritional Therapy \& Metabolism, 28, p.

[17] Orish, V.N., Ansong, J.Y., Anagi, I.B., Onyeabor, O.S., Sanyaolu, A.O. and Iriemenam, N.C. (2015) Malaria and Associated Co-Morbidity in Children Admitted with Fever Manifestation in Western Ghana: A Retrospective Study. The Journal of Infection in Developing Countries, 9, 1257-1263. https://doi.org/10.3855/jidc.6316

[18] Meinzen-Derr, J.K., Guerrero, M.L., Altaye, M., Ruiz-Palacios, G.M. and Morrow, A.L. (2004) Duration of Exclusive Breastfeeding and Risk of Anaemia in a Cohort of Mexican Infants. In: Pickering, L.K., Morrow, A.L., Ruiz-Palacios, G.M. and Schanler, R.J. Eds., Protecting Infants through Human Milk, Springer, Boston, 395-398. https://doi.org/10.1007/978-1-4757-4242-8_49

[19] Luo, R., Shi, Y., Zhou, H., Yue, A., Zhang, L., Sylvia, S., Medina, A. and Rozelle, S. (2014) Anaemia and Feeding Practices among Infants in Rural Shaanxi Province in China. Nutrients, 6, 5975-5991. https://doi.org/10.3390/nu6125975

[20] Chandyo, R.K., Henjum, S., Ulak, M., Thorne-Lyman, A.L., Ulvik, R.J., Shrestha, P.S., Locks, L., Fawzi, W. and Strand, T.A. (2016) The Prevalence of Anaemia and Iron Deficiency Is More Common in Breastfed Infants than Their Mothers in Bhaktapur, Nepal. European Journal of Clinical Nutrition, 70, 456-462.

[21] Leal, L.P., Batista Filho, M., Lira, P.I.C.D., Figueiroa, J.N. and Osório, M.M. (2011) Prevalence of Anaemia and Associated Factors in Children Aged 6 - 59 Months in Pernambuco, Northeastern Brazil. Revista de Saúde Pública, 45, 457-466. https://doi.org/10.1590/S0034-89102011000300003

[22] Brugnara, C., Zurakowski, D., DiCanzio, J., Boyd, T. and Platt, O. (1999) Reticulocyte Hemoglobin Content to Diagnose Iron Deficiency in Children. Journal of American Medical Association, 281, 2225-2230. https://doi.org/10.1001/jama.281.23.2225

[23] Gomber, S., Madan, N., Lal, A. and Kela, K. (2003) Prevalence \& Etiology of Nutritional Anaemia among School Children of Urban Slums. Indian Journal of Medical Research, 118, 167-171.

[24] Schultz, B.M. and Freedman, M.L. (1987) 2 Iron Deficiency in the Elderly. Baillière's Clinical Haematology, 1, 291-313. https://doi.org/10.1016/S0950-3536(87)80004-5

[25] Janus, J. and Moerschel, S.K. (2010) Evaluation of Anaemia in Children. American Family Physician, 81, 1462-1471. 